\title{
Peertechz
}
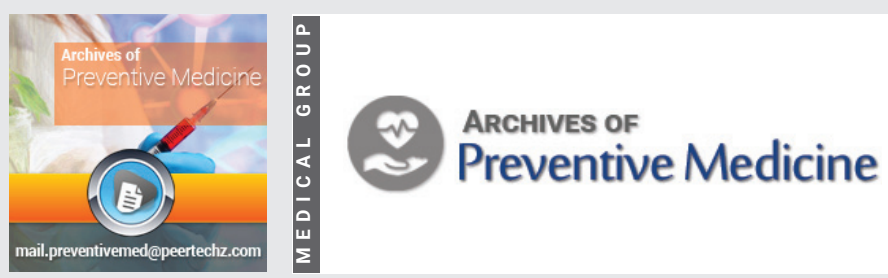

Research Article

\section{COVID-19: Notes on its Etiology, Pathogenesis and Mediation}

Received: 17 September, 2020

Accepted: 24 September, 2020

Published: 25 September, 2020

*Corresponding author: Richard D Sauerheber, STAR Center, Palomar Community College, San Marcos, CA 92069, USA, E-mail: RSauerheber@palomar.edu

https://www.peertechz.com

Check for updates

\author{
Richard D Sauerheber ${ }^{1 *}$ and Kalvin McCallum² \\ 'STAR Center, Palomar Community College, San Marcos, CA 92069, USA \\ ${ }^{2}$ Department of Bioengineering, University of Massachusetts, Lowell, MA, USA
}

\begin{abstract}
The susceptibility of the SARS novel CoV-2 virus to environmental temperature has become recently known and suggests that freshly boiled steam or heated air at an appropriate temperature may be a useful prophylactic and mitigant in the treatment of COVID-19 infection. A laser thermometer was used to measure the temperature of a steam column as a function of height above boiling water to determine the conditions known to partially or fully inactivate viral infectivity. The rationale for the possible treatment is explained. An overview of virus properties, Covid-19, and the worldwide pandemic is presented. The percentage lethality in confirmed cases monitors aspects of the pandemic in the U.S. and the world. The world lethality and overall U.S. lethality are approximately $4.2-4.4 \%$ as of July 18,2020 . However ten States have a higher value, as high as $9.2 \%$ for Connecticut, while 14 States are below the world average with California at $1.9 \%$. Possible reasons for these differences are discussed.

Disclaimer: Statements and suggestions in this article should not replace treatment given by a physician, and any change in treatment or prophylactic protocol must be discussed and approved by a physician before being undertaken. Clinical sequelae associated with infection vary widely among people, and any procedure that might be advisable in one stage of an infectious process may not be effective or may be contraindicated in another stage. Breathing steam or heated air must not be too severe to scald airway tissue and must not be so vigorous as to spread viral particles in airways. This information is open for discussion and further examination.
\end{abstract}

\section{Introduction}

The novel severe acute respiratory syndrome coronavirus SARS-CoV-2 is an RNA virus with a surface arrayed with crown-topped protein spikes that project $24 \mathrm{~nm}$ outward from its lipid envelope (Figure 1). These proteins, labeled spike S proteins because of their shape, form the outer surface material that interacts with particular protein binding sites. This unusual virus interacts with the angiotensin converting enzyme (ACE) protein on human type 2 pneumocytes to elicit an infectious process having variable outcomes, ranging from moderate symptoms to lethal pneumonia. This virus is highly transmissable among humans and rapidly caused a worldwide pandemic and thus is a modification of earlier known forms of coronavirus including CoV and MERS.

The transmission electron microscopic image of intact viruses (lower photo) showing the protruding spike proteins were presented for the public by the NIAID Rocky Mountain Laboratory, Hamilton, Canada (April, 2020) available at: $\quad$ file:///C:/Users/RSauerheber/Documents/Novel\%20

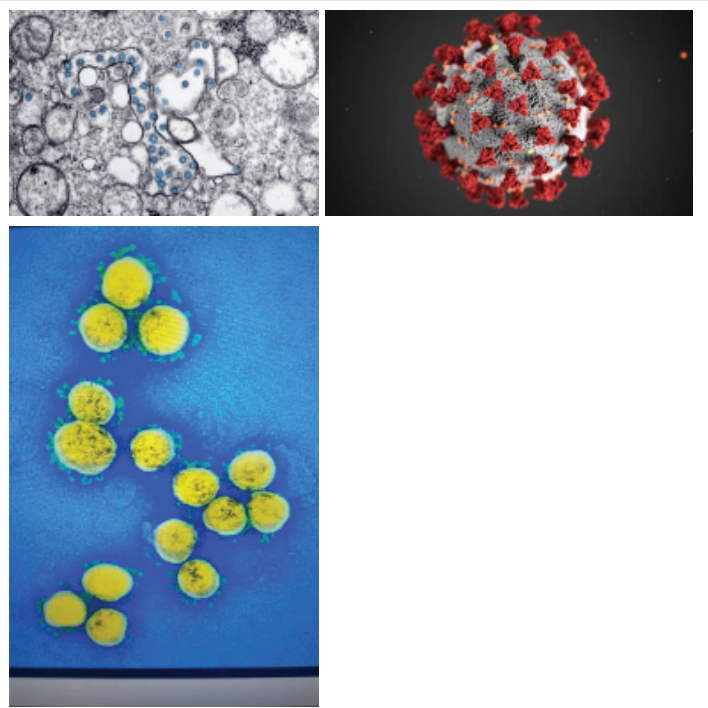

Figure 1: Transmission electron micrograph of the first Covid-19 infected patient. The small round viral particles were colorized for visualization (upper left). Representation of the Covid-19 disease-causing SARS CoV-2 virus with its protruding spike $S$ proteins extending from the lipid membrane which encloses internal RNA (upper right). These photos are from the U.S. CDC. 
Coronavirus $\% 20$ SARS-CoV-2\%20_\%20Transmission $\% 20$ electron\%20microgr\%E2\%80\%A6\%20_\%20Flickr.html The appearance closely resembles that of the SARS and MERS viruses, all being coronaviruses.

These viruses readily infect human alveolar cells, which biochemically replicate virus particles that destroy the infected cell and spread to infect additional cells. The virus has been found to spread into systemic circulation and has been isolated from several organs. Unlike the AIDS RNA virus (Figure 2) that also contains a lipid bilayer with protruding proteins that generate antibodies that do not neutralize infectivity, it is hoped that the protruding surface spike proteins on CoV-2 will be amenable to neutralization with a suitable vaccine antibody. Recent studies with monkeys inoculated with antibody showed total resistance to intentional exposure to the virus. Other RNA viruses for which there are effective vaccines include Ebola $\mathrm{H} 1 \mathrm{~N} 1$, and SARS where antibodies are raised against either an isolated protein component of the virus or to the inactivated virus. There is no vaccine that has been found effective for the AIDS RNA virus, where antibodies bind surface proteins but do not neutralize infectivity (personal communication Dr. Larry M. Gordon, former co-worker)

CoV-2 virus particles after infection and spreading to lung cells can enter the bloodstream and affect other organs. $30 \%$ of those infected require kidney dialysis. A study from Wuhan, China on pregnant women who became infected with the virus in the third trimester reported that none of the newborn infants tested positive, and amniotic fluid was also negative for the virus in all cases. The newborns were isolated from the mothers until recovery. This suggests that the virus does not penetrate the placental barrier. The chief most serious event is destruction of alveolar cells causing pneumonia. Pneumonia is an inflammation of lung tissue caused by either viral or bacterial infection with accumulation of fluid in alveolar spaces. Historically bacterial pneumonias have been more dangerous than viral because immune mechanisms can neutralize virus particles, while bacterial infections can be lethal unless an effective antibiotic is administered in time. Covid-19 pneumonia appears to reverse this adage where typically $6 \%$ of those with the infection do not survive.

The normal biochemical response to lung cell infection is mounted by the immune system and in some individuals this can be so intense to cause fluid accumulation in infected alveoli which is the typical cause of lethality. The virus can directly weaken the heart as well. ACE protein is present in cells of the oral mucosa bronchial airways as well as the mucosa of the GI tract and endothelial cells lining blood vessels.

Protein function is generally impaired efficiently by exposing a given protein to a non-physiologic temperature or $\mathrm{pH}$. Common examples are shown in Figures 3,4 for the $\mathrm{pH}$ dependence of sucrase activity and for the temperature dependence of the conformational structure of insulin. One possibility is that coronavirus particles are so small (70-90 $n m$ ) [1] that the exposed set of protruding proteins extending into the surrounding solution may respond to temperature and $\mathrm{pH}$ alterations similar to a soluble protein. It is important to note that at least one mutant coronavirus with spike S proteins has impaired binding and 100 fold less growth in human kidney cells after chronic exposure to a mere $40{ }^{\circ} \mathrm{C}\left(104^{\circ} \mathrm{F}\right)$, while other coronavirus forms were not affected at this low fever temperature [2]. Further, merely lowering the $\mathrm{pH}$ from 7.4 to 7.0 changes the conformation of insulin sufficiently to completely block the insulin stimulation of glucose transport in intact cells. This is attributed to changes in binding, where

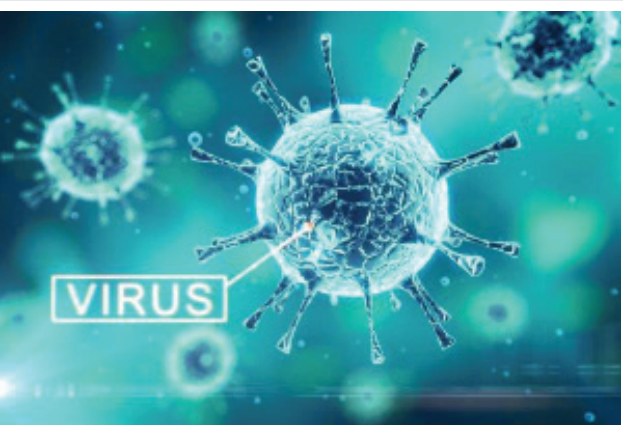

Figure 2: The physical appearance of the highly magnified HIV (human immunodeficiency virus) AIDS (acquired immunodeficiency disease syndrome) virus. Unfortunately, antibodies made that bind the proteins protruding from the lipid envelope do not prevent infectivity. Instead, HIV is treated with RNA replication blocking drugs

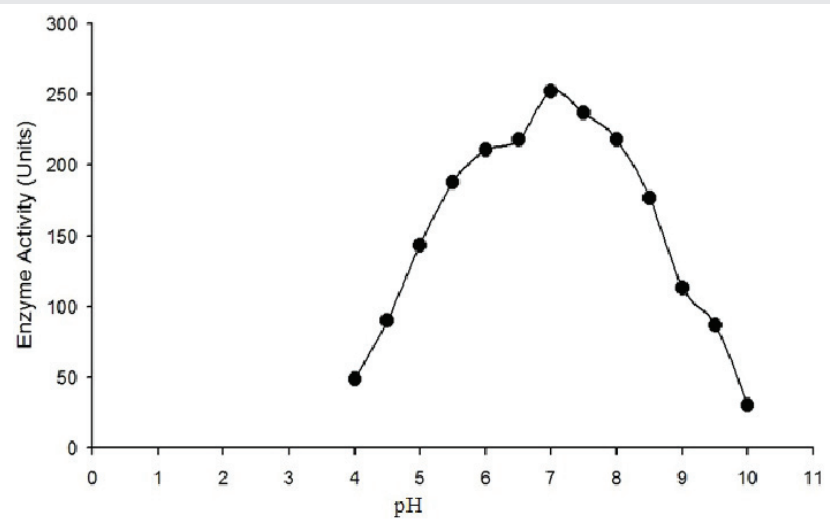

Figure 3: pH dependence of the activity of sucrase.

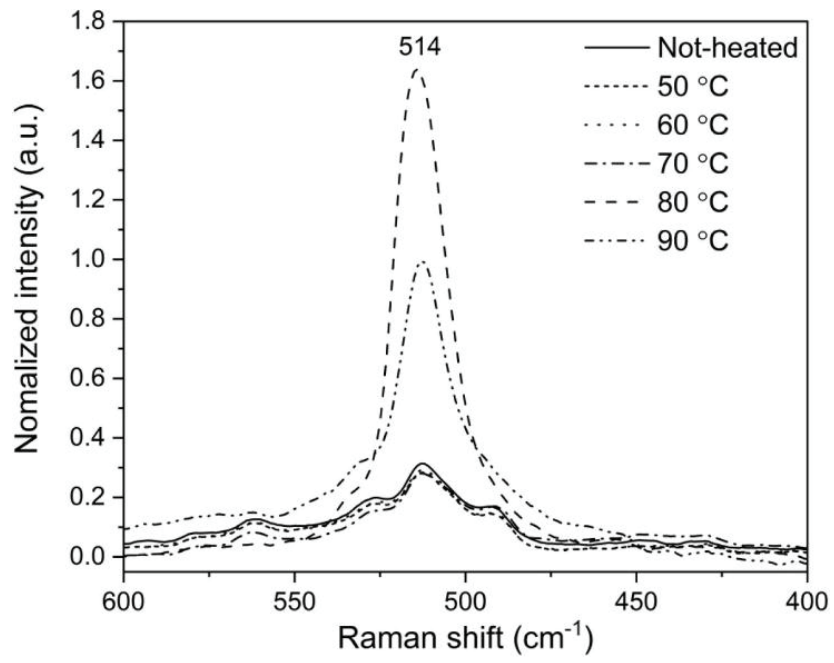

Figure 4a: Temperature dependence of the conformation of insulin as detected through Raman spectra of the protein in solution. Data are from [3] 
a 6 fold lower binding of insulin to its receptor occurs over a mere drop of $1 \mathrm{pH}$ unit from 7.8 to 6.8 [6]. (Extracellular and arterial blood $\mathrm{pH}$ is tightly regulated by physiologic buffers and proper breathing to maintain the $\mathrm{pH}$ at 7.4 ).

Spike S proteins on coronaviruses are classed as type I fusion proteins and at least one type is irreversibly denatured at $\mathrm{pH} 8$. The U.S. CDC has stated that, unlike the hepatitis virus (Figure 5 ), there is no evidence the Cov-2 virus infection is transmitted by consuming foods. One possibility is that the spike protein is destroyed by digestive proteases or by the alkaline bicarbonate secretions in the small intestine.

The spike proteins undergo significant conformational change upon binding to cell surface receptor proteins that may be sensitive to temperature. One spike protein form was not denatured during a brief five minute exposure to 70-80 ${ }^{\circ} \mathrm{C}$ (158-176 $\left.{ }^{\circ} \mathrm{F}\right)$ [7]. However, an important recent study [5] found that the SARS CoV-2 virus infection of human embryonic kidney cells was half inhibited after a two hour exposure to $43^{\circ} \mathrm{C}\left(109{ }^{\circ} \mathrm{F}\right)$ and was completely obliterated at $48^{\circ} \mathrm{C}\left(118{ }^{\circ} \mathrm{F}\right)$ for two hours. If the exposure does not permanently denature RNA or the spike protein, the treatment could nevertheless block binding of the virus to ACE protein. These findings are consistent with measures of coronavirus viability as a function of time on surfaces exposed to various temperatures (Figure 6).

Steam treatment of the face and the oral cavity have been used to cure acne and to treat bacteria causing bleeding gums (unpublished). A controlled study conducted on patients with lower respiratory tract infections, some with pneumonia, indicated substantial shortening of recovery time and lowering of hypoxia caused by steam inhalation in tents [7]. Steam has been recommended to open nasal ostia in cases of infectious sinusitis [8]. It is therefore hypothesized that the combination of heating and $\mathrm{pH}$ lowering of the free virus in bronchioles and alveoli prior to infection of lung cells might impair infection of lung tissue, and later in an infectious episode may mitigate further spread from virions present in nasal and bronchial airways. It is possible that inhaling steam or lemon juice acidified steam coupled with nasal lavage with a "netty

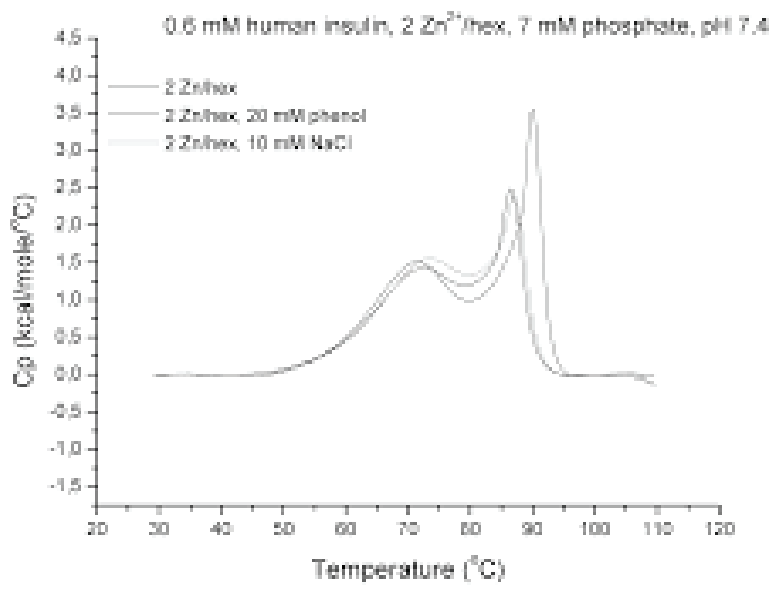

Figure 4b: Temperature induced denaturation of insulin. A steam temperature of $165{ }^{\circ} \mathrm{F}$ corresponds to $71^{\circ} \mathrm{C}$, at which insulin is thoroughly denatured. At more modest temperatures, insulin function is lost before full denaturation.

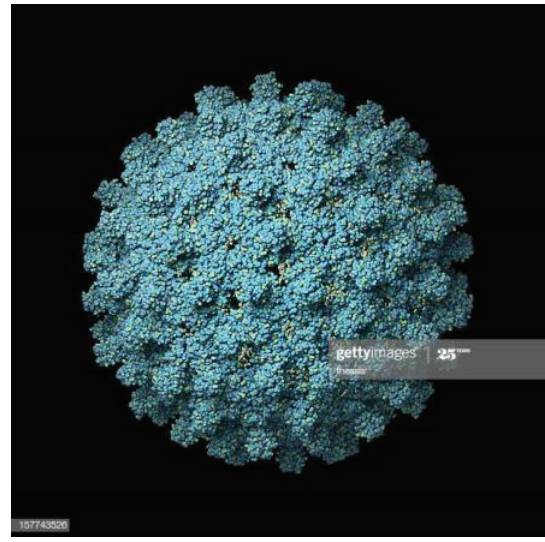

Figure 5: The appearance of the highly magnified hepatitis virus. Note the very different surface features. Hepatitis infection readily occurs after ingesting contaminated food, so the virus surface is highly resistant to significant damage from proteolytic enzymes in the gastrointestinal tract.

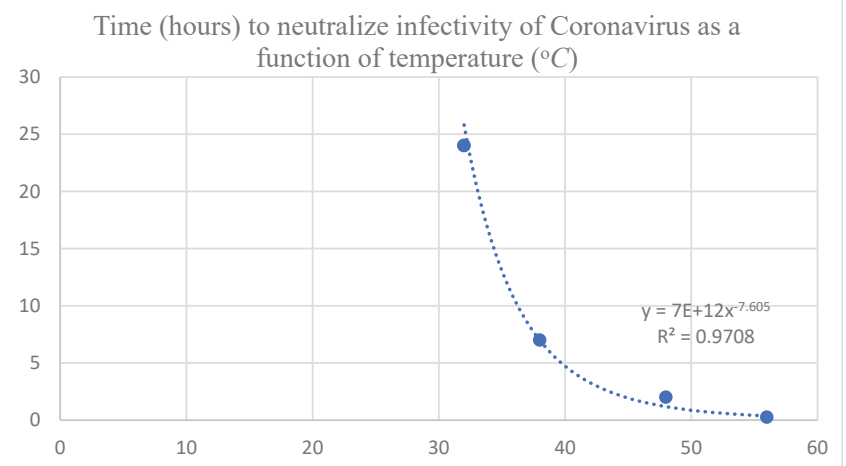

Figure 6: The time required to obliterate CoV-2 virus infectivity is shown as a function of temperature. Most of the points were from published values for virus survival on surfaces exposed to varying ambient temperature [4]. The third value however is from the Chinese study conducted in Wuhan showing conditions that obliterate the infection of human kidney cells in culture [5]

pot" containing sanitized pre-boiled lemon water cooled to a tolerable temperature may improve outcomes in individuals infected with the novel virus.

Although dry skin can be scalded at a liquid temperature of $155^{\circ} \mathrm{F}\left(68^{\circ} \mathrm{C}\right)$, moist tissue in the oral, nasal, and bronchial airway cavities withstand much higher temperatures. Warming airways to approximately $160^{\circ} \mathrm{F}\left(71^{\circ} \mathrm{C}\right)$ for several minutes a few times daily could be a useful practice for generally preventing viral infections of the upper respiratory tract. This temperature denatures the structure of insulin (Figure 4 ) and blocks insulin function, and a 10 minute exposure is known to degrade RNA.

\section{Results}

Here reported is the temperature of steam as a function of height above boiling water, and also optimum conditions to inhale acidified steam (see Figure 7 for the system used). Organic acids in lemon juice can co-distill with water. Acidified steam from boiling lemon juice treated water may provide additional benefit. The $\mathrm{pH}$ of steam can be adjusted to a safe but effective level with properly diluted amounts of lemon juice (pH 2.5). 
Steam temperature as a function of height above a boiling water pot with 5 inch $(14 \mathrm{~cm})$ diameter. The column of steam was measured on a plastic ruler with an infrared thermometer (Radio Shack, Cat. No. 22-170 IR thermometer). Room temperature was $64^{\circ} \mathrm{F}\left(18{ }^{\circ} \mathrm{C}\right)$. The apparatus used is pictured in Figure 7A and the values are plotted in Figure 7B.

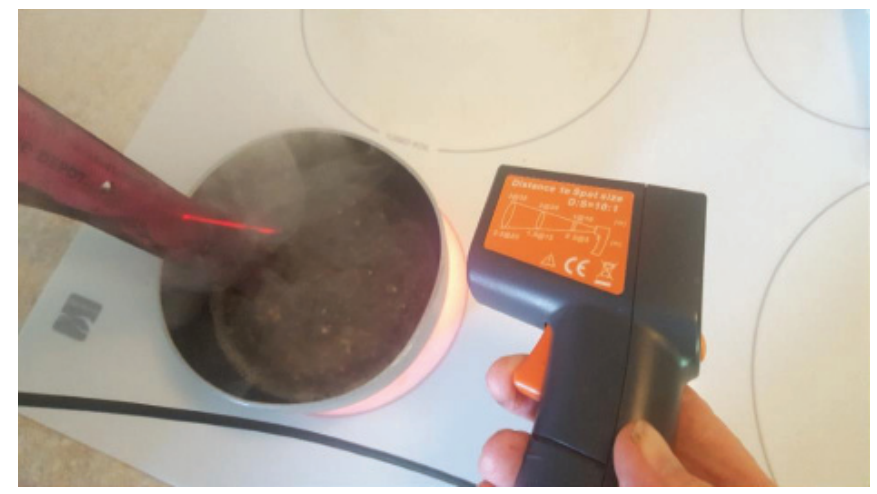

Figure 7a: Apparatus for measuring the temperature of steam as a function of height above a boiling water surface. Temperatures were measured with an infrared thermometer. The light ray from the device, invisible in air, is visible in the steam cloud, much like in a cloud chamber. The ray reflects off a plastic ruler which formed a temperature gradient above the water.

Temperature $\left({ }^{o} \mathrm{~F}\right)$ as a function of steam column height (in)

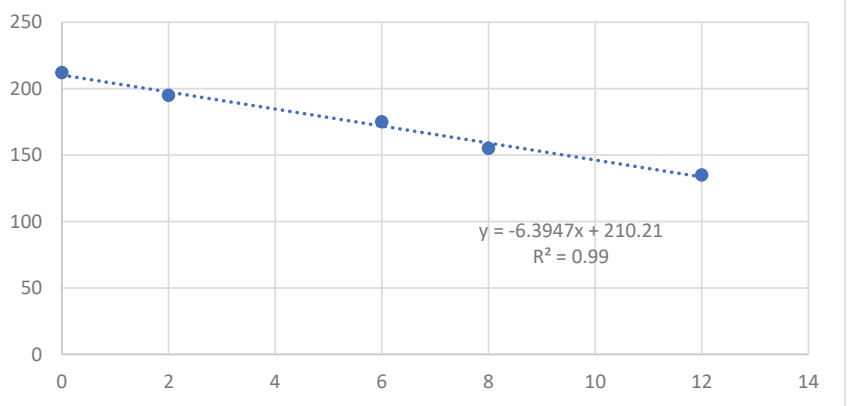

Figure $7 \mathbf{b}$ : Temperature ${ }^{\circ} \mathrm{F}$ of a column of steam as a function of distance (inches) above the liquid surface.

One possibility to consider then is that prolonged exposure of the respiratory tract to $48{ }^{\circ} \mathrm{C}\left(118{ }^{\circ} \mathrm{F}\right)$ temperature might impair infectivity of these viral particles after being inhaled. Steam inhalation could be used to mimic the external conditions above in a feasible, safe manner. For example, the highest temperature on record on earth occurred multiple times at various locations, including Death Valley, CA, Tunisia, Iraq, and Kuwait at $130{ }^{\circ} \mathrm{F}\left(54^{\circ} \mathrm{C}\right)$. Furthermore, treating airways with steam heat is far less perturbing since it does not require warming the entire body. Quick inhalation and immersion into a steam field could be done at even higher temperatures that would avoid any skin surface overheating while minimizing treatment exposure time. Thermodynamic principles for effects of heat on protein function suggest that equivalent treatments would be $48^{\circ} \mathrm{C}\left(118^{\circ} \mathrm{F}\right)$ for two hours, or $58^{\circ} \mathrm{C}\left(136^{\circ} \mathrm{F}\right)$ for one hour, or $68^{\circ} \mathrm{C}\left(154^{\circ} \mathrm{F}\right)$ for 30 minutes, or $78^{\circ} \mathrm{C}\left(172{ }^{\circ} \mathrm{F}\right)$ for 15 minutes, although the latter option would require repeatedly entering the steam field with each quick inhalation.
The duration of time for steam treatment in addition to steam temperature are both critical in destroying viral infectivity. In one study, steam breathing was reported ineffective in treating respiratory illness, but the temperature of the steam was not assessed, and the duration of treatment was short. Studies with polymerase chain reaction PCR for replicating RNA for research purposes note that RNA is degraded at $50^{\circ} \mathrm{C}\left(148{ }^{\circ} \mathrm{F}\right)$. Other studies indicate that denaturation of RNA requires $70{ }^{\circ} \mathrm{C}(158$ ${ }^{\circ} \mathrm{F}$ ) and still others suggest RNA is highly heat stable, where structure can return after heating unfolds the tertiary structure. In these studies the duration of time the RNA is exposed to these temperatures determines the extent of degradation. Proteins commonly become dysfunctional at $50{ }^{\circ} \mathrm{C}\left(148{ }^{\circ} \mathrm{F}\right)$. Basically if one tested positive for the virus, a goal would be to inhale all the steam energy that could be safely tolerated in an attempt to denature the viral spike protein and RNA.

There are large discrepancies among the public statements made regarding the length of time that coronavirus-2 (SARS$\mathrm{CoV}-2)$ remains infective upon residing on various surfaces. Published data indicate that the virus at moderate temperature is not efficiently eliminated in infectivity until about 9 days. At $90^{\circ} \mathrm{F}\left(32^{\circ} \mathrm{C}\right)$ the effective killing time is about 24 hours and at $100^{\circ} \mathrm{F}\left(38^{\circ} \mathrm{C}\right)$ it is about 7 hours, and at $132^{\circ} \mathrm{F}\left(55.6^{\circ} \mathrm{C}\right)$ survival is about 15 minutes [4] (Figure 6). These results are fully consistent with the aforementioned finding that coronavirus infection of human kidney cells is obliterated at $48{ }^{\circ} \mathrm{C}\left(118{ }^{\circ} \mathrm{F}\right)$ for two hours. These comparisons are important because steam burns are usually not as severe as boiling water burns even though steam molecules contain more heat energy. This is because steam vapor is disseminated into a larger volume. So the close comparison between temperature and time exposures for both ambient air and incubation media that obliterate infectivity suggest that proper steam exposure might replicate this effect.

\section{Discussion}

These data taken together imply that one precaution anyone could take who suspects is infected, or is infected, would be to breathe steam at a proper temperature and time of exposure. This is a simple home treatment, breathing steam at a temperature that is tolerable above a pot of boiling water (212 ${ }^{\circ} \mathrm{F}, 100^{\circ} \mathrm{C}$ ). This could be done daily or in some cases at four hour intervals to help minimize the effects of the infection, where recent studies indicate viral infectivity is obliterated at $167^{\circ} \mathrm{F}$ $\left(75^{\circ} \mathrm{C}\right)$ for 30 minutes [9]. A rule of thumb in thermodynamics is that a process may be accelerated by a factor of two for every $10{ }^{\circ} \mathrm{C}$ rise in temperature. So the obliteration of infectivity in kidney cells at $48^{\circ} \mathrm{C}\left(118^{\circ} \mathrm{F}\right)$ for two hours would be achieved at $58^{\circ} \mathrm{C}\left(136^{\circ} \mathrm{F}\right)$ for 1 hour and $68^{\circ} \mathrm{C}\left(154^{\circ} \mathrm{F}\right)$ for 30 minutes. Since complete neutralization is not necessary, a 20 minute exposure to $\sim 150^{\circ} \mathrm{F}$ steam, which is easily tolerable, could be an effective mitigant if performed soon after a possible exposure.

For individuals with breathing difficulty, or to ensure most efficient penetration of steam into bronchioles and alveoli, steam could be administered through a nebulizer. These devices use a slight positive pressure to increase the penetration of inhaled medicines delivered as mists, most commonly for cases of asthma. 
The long term survival of $\mathrm{CoV}-2$ on surfaces at modest temperature is particularly troubling and may be an important feature of the high incidence of transmission, being an indirect route between people. Mailed packages can arrive quickly after being sent from infected locations or handled by infected people, and since asymptomatic people can transmit the virus which can last for so long on surfaces, one suggestion would be that mail generally could be sanitized on the outside or the contents could be opened several days after arrival.

Since coronaviruses are RNA based, drugs used that are FDA approved for treatment on the use of RNA-based AIDS virus should be considered as possible treatments. Recent studies indeed indicate significant improvements in the condition of Covid-19 patients treated with remdesivir, a nucleoside analog that slows replication of the viral RNA. The widespread hope that hydroxychloroquine, the antimalarial that de-glycosylates the ACE protein, would be an effective treatment has been largely tampered. Although much evidence has been published that this agent has antiviral effects in vitro, it has been found that the coronavirus infection compromises heart function and this drug can prolong $\mathrm{Q}-\mathrm{T}$ intervals on electrocardiograms. Indeed a clinical trial of this drug in Covid-19 patients in Brazil had to be halted for increased cardiovascular mortality during the trial. The largest study to date at the University of Virginia found that Covid-19 patients treated with the drug experienced $22 \%$ death rates compared to $11 \%$ without the drug. A similar finding was observed for the combined use of hydroxychloroquine and azithromycin. The FDA had little choice but to place warnings on the use of this agent in Covid-19. The largest controlled clinical trial done so far recently found no benefit for use of the drug in Covid-19 patients. There will be no single treatment that would readily arrest an ongoing symptomatic infection, but the combined use of extracellular steam plus RNA replication medicines such as remdesivir, acting intracellularly, could be a possible approach, as well as agents such as dexamethasone that mitigate the cytokine storm [10].

Vaccines targeting various parts of the virus are being developed in various labs around the world. A vaccine that has shown to be effective in macaques has now been developed in the U.K. and in China [11]. The Oxford vaccine is a nonreplicating adenovirus containing the SARS $\mathrm{CoV}-2$ spike protein which generated both cellular and humoral antibody in macaques and recently in man. Since the lethality of Covid-19 is argued to be due largely to an immune overreaction in a cytokine storm, vaccination for the condition may be problematic, but the data on macaques do not show evidence of such an overreaction while preventing the condition in inoculated animals and human volunteers. However, it remains possible that an immune exaggerated response might still be a problem after a later re-exposure to the virus, and this remains to be studied. Many vaccines include aluminum as an artificial adjuvant. It is hoped that any widespread use of a vaccine will not contain aluminum because the dose injected is larger than what would enter the circulation after ingesting an FDA allowed maximum amount of this metal ion in foods. And an unnatural stimulation of the immune response with adjuvants should not be considered viable when the cytokine storm and an overreaction is to be avoided.
It is expected that antibodies raised to the viral RNA in some studies would not be as effective since viral RNA would be released and exposed only inside cells. The RNA sequence [12] of this novel virus has become altered over time in the human population, causing a glycine to replace an aspartate at position 614 in the spike protein. This is a region where antibodies typically bind and one can only hope that antibody effectiveness is not reduced by this mutation. This amino acid substitution has been detected mostly in Europe and the Eastern U.S. and has been the predominant form found in those infected. This form appears far more infective than the original sequence. The Oxford vaccine directed against the virus spike protein induced both humoral circulating antibody and cellular immunity which destroys infected cells and this immune response has lasted for 3 months as of July, 2020 [13]. It is hoped that this particular vaccine will not require yearly vaccinations as do other coronavirus vaccines for the flu.

Lemon juice is typically about $\mathrm{pH} 2.5$ with a hydrogen ion molarity of $0.003 \mathrm{M}$. Diluting lemon juice into water 1:3,000 produces a steam $\mathrm{pH}$ of approximately 6 . Breathing acidified steam 6 inches above a boiling pot produces $175^{\circ} \mathrm{F}\left(79^{\circ} \mathrm{C}\right)$ steam at pH 6 which alters substantially the function of soluble free floating proteins that normally have maximal function at $\mathrm{pH}$ 7.2 and $37^{\circ} \mathrm{C}\left(98^{\circ} \mathrm{F}\right)$. Proteins in the lipid bilayer of cell surface membranes are very resistant to externally applied steam since the protein is shielded by surrounding lipid, and the cell membrane does not warm significantly from the external steam being shielded by layers of aqueous fluid or alveolar secretions.

If steam is unavailable it is also possible to use a room space heater to generate heated air for breathing. The temperature could be measured as indicated in Figure 7A to ensure sufficient heating for a given time to compare with the effect of steam inhalation. Heated air from a 1,500 Watt room space heater measured at a $20 \mathrm{~cm}$ distance was about $120{ }^{\circ} \mathrm{F}\left(49^{\circ} \mathrm{C}\right)$. It is important to stress that in no case should heat be inhaled in such a manner that would cause discomfort.

Because the ACE protein in type 2 pneumocytes is highly expressed in patients treated with ACE inhibitors to mitigate high blood pressure, it has been widely suggested that these individuals might be much more sensitive to coronavirus infection. It is very possible that the increased level of this protein in the elderly may explain why Covid-19 lethality in the elderly is typically a much higher percentage of confirmed cases. On the other hand, a recent study reported that the use

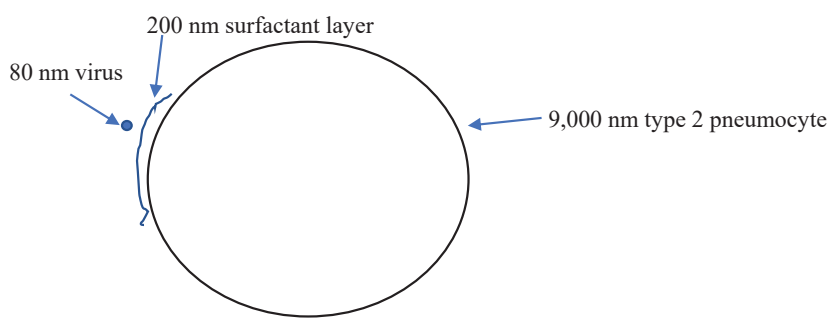

Figure 8: Relative dimensions of the SARS Cov-2 coronavirus, the lung alveolar surfactant layer, and a type 2 pneumocyte in a theoretic cross section are approximated to scale. 
of ACE inhibitors in Covid-19 patients did not affect disease outcome [14]. One possibility is also that the use of these inhibitors might impair infection since the enzyme is inhibited, and that discontinuance of the drugs during an infection might worsen the condition due to expression of the more highly uploaded ACE protein. Moreover, it has been reported that an increased incidence of blood clotting occurs in Covid-19 patients. Additional studies might clarify this point.

Type 2 pneumocytes are responsible for secreting surfactant to maintain pliable functional alveoli. Type 1 pneumocytes undergo gas exchange between oxygen and $\mathrm{CO}_{2}$. Type 1 are $50 \mathrm{u}$ but type 2 are $9 u$. Virus particles at $80 \mathrm{~nm}$ are 112 times smaller in diameter than the relatively small type 2 cells. The surfactant layer lining alveoli ranges from $0.1 \mathrm{um}$ on cell surfaces to 0.9 $u m$ at alveolar cell junctions, with an average of $0.2 \mathrm{um}$ [1].

A drawing showing the relative dimensions of these elements in a theoretic alveolar cell cross section are shown in Figure 8. Viral particles after a brief public exposure would initially line the nasal passages and possibly bronchial airway linings or deeper, depending on the number of droplets inhaled and the tidal volume per breath at the time and other factors. Figure 9 is a side view of the passageways for airflow in humans where bronchi branch from the trachea and upon entering the lungs branch into smaller bronchioles. The depth to which steam or heated air needs to be applied through these passages is determined by the extent of the infection. If one is suspected of exposure to the virus, a steam treatment would be the best choice to help prevent the virus from infecting underlying tissue and thereby spreading. The rationale for this is the fact that virus particles exist in airways for a significant time before penetrating beneath mucus or surfactant layers, during which virions would be susceptible to thermal degradation. Although the length of this time period is unknown, it is important to note that initial symptoms of Covid-19 do not appear until about 4-5 days after exposure.

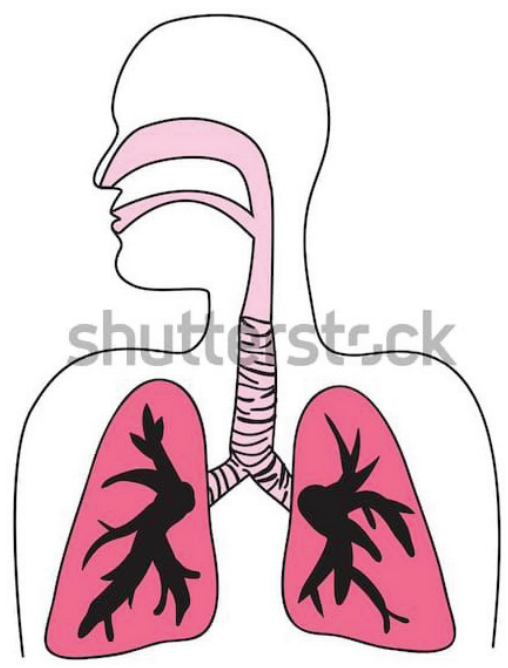

www.shutterstock com $\cdot 54080260$

Figure 9: Side view of airways from nasal passages to lung bronchioles and alveoli. ACE proteins on endothelial cell surfaces are present throughout the respiratory tract and also in oral mucosa. Steam penetrates all airways and the oral cavity when inhaled.
Steam or heated air treatment would be expected to be most useful for asymptomatics who tested positive with a nasal, oral, or saliva test. Steam might mitigate subsequent infection of lung cells. In symptomatic stages where cells have been infected and virus particles have entered the blood, steam could be a mitigant to help slow infection of additional sites from the airways. In late stage illness with alveolar fluid accumulation, steam use would be less useful, but steam has been used in cases of pneumonia and severe congestion from viral infections. As stated, one study found decreased time to recovery when using steam compared to controls.

Steam or heated air use is possible at home during self quarantine. Ideally instead of simple self isolation at home after a positive test, one could self-isolate with access to a heating unit to generate steam or hot air and sinus lavage procedures daily to improve the chance of preventing serious illness. Unsupervised steam inhalation by children has led to scalding and usually is discouraged, unless a carefully temperature controlled system is used. In adults, effective steam inhalation can be obtained by inserting a plastic or metal funnel cone into the appropriate steam column position to conduct steam into the oral cavity and thus avoid exposure of facial surfaces. Steam tents over the head could be used but must have an open side for ventilation.

The goal of steam or heated air inhalation is to prevent serious infection. In cases where exposure to the virus was expected but significant symptoms have not yet appeared it is not expected that this would require total irreversible denaturation of the virus particles, but rather structural alterations sufficient to minimize infectivity and prevent the virus from producing serious or lethal symptoms. All virus particles are of differing size, from 70 to $90 \mathrm{~nm}$, and thus require differing heating times to achieve a denaturing temperature. Proteins vary in temperature and time needed to achieve either functional block, permanent functional block, or complete irreversible denaturation. Baking to denature proteins in meat is complete at approximately $160^{\circ} \mathrm{F}\left(71^{\circ} \mathrm{C}\right)$ for safe consumption.

Figure 10 shows more efficient systems that could be used for steam production if one did not want to move into the steam field to inhale and then leave the field between breaths to avoid overheating facial skin. In these devices steam heat generation is extremely energetic so it is necessary to measure the temperature of the steam actually inhaled at the end of the mouthpiece straw tube, which must be adjusted to a height sufficient to achieve a temperature of about $140-150{ }^{\circ} \mathrm{F}$. (60$65.6^{\circ} \mathrm{C}$ ) In the commercial steamer the temperature ranges from about $190{ }^{\circ} \mathrm{F}\left(87.8{ }^{\circ} \mathrm{C}\right)$ in the bottom tray to $180{ }^{\circ} \mathrm{F}(82.2$ ${ }^{\circ} \mathrm{C}$ ) in the upper tray so the funnel and tubing produce steam at about $150{ }^{\circ} \mathrm{F} .\left(65.6^{\circ} \mathrm{C}\right)$. Meat protein is completely denatured and cooked for consumption in the bottom tray in seven minutes and the upper tray in nine minutes. The coronavirus again requires $140{ }^{\circ} \mathrm{F}\left(60{ }^{\circ} \mathrm{C}\right)$ ) for 30 minutes for complete destruction. The steamer when half full lasts 30 minutes. The difference in cooking times is due to the length of time required for all the meat proteins to reach $160^{\circ} \mathrm{F}\left(71^{\circ} \mathrm{C}\right)$ for total irreversible destruction. For the virus the goal of $140^{\circ} \mathrm{F}\left(60^{\circ} \mathrm{C}\right)$ 


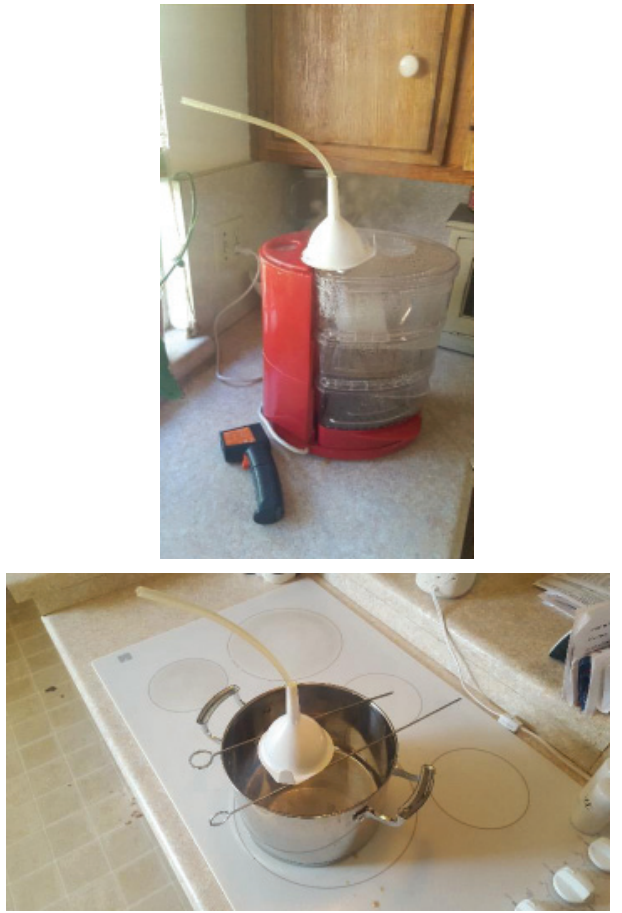

Figure 10: Apparatus for delivering hot steam for inhalation.

for 30 minutes would achieve complete destruction, but again either lower temperatures or shorter times regularly could be sufficient to minimize infectivity.

Steam inhalation should not be overdone to the point of causing unnecessary discomfort. Although hot steam is expected to inactivate virus particles in the open airway spaces, it would be prudent to exercise caution so that the speed with which steam is inhaled should be no greater than normal breathing, to avoid viral particles from penetrating more deeply in the airways. Heated air from a space heater, rather than fro a blower, would therefore also be preferred. Dry heated air has the advantage of being perhaps more effective at heating airway tissue, but the disadvantage of drying out secretions that help remove foreign particles. 15 minutes of dry heated air breathing could be followed with 15 minutes of steam to mitigate this. Note that the usual temperature range in a sauna bath is about $150-170^{\circ} \mathrm{F}\left(66^{-}-77^{\circ} \mathrm{C}\right)$.

The time and temperature required to destroy infectivity of the coronavirus in airways by inhaling steam may be estimated by again turning to Figure 6 . Heating at a high temperature but too brief a time is insufficient to achieve total destruction, and heating for a long time but at too low a temperature is also insufficient. The time-temperature curve must be reached or exceeded to completely destroy virus infectivity. However, it is not necessary to achieve complete irreversible denaturation, but rather a minimization of infectivity. This curve is a guide, and is not necessarily strictly required to prevent serious infection. As promising as this discussion sounds, it must be emphasized here that although steam can destroy the coronavirus in vitro on external surfaces and could block infectivity of human cells in tissue culture, there are no studies of steam use in patients with Covid and any effectiveness is at this point not proven in clinical studies.
A simple but important action is to sleep upright, not lying down. This is because mucus secretions and pus when prone, due to gravity, causes inhaled air to simply flow atop the liquid which continues to accumulate and provide a growth medium for infectious agents. Sleeping upright causes fluid to span an airway lining and force a cough which expectorates the material. Also regularly changing positions while sleeping helps prevent damage from fluid buildup. These actions are the single most important an individual can do to combat the effects of respiratory infection.

Most water droplets released during human breathing are on the order of $1 \mathrm{um}$ in diameter [15]. Coughing produces larger droplets that travel less distance than smaller particles and settle out of the atmosphere more readily also. $1 \mathrm{um}$ diameter droplets could contain several viral particles, since the virus diameter is 12 times smaller $(1 \mathrm{um} / 80 \mathrm{~nm}=12.5)$. A minimum but uncertain large number of viral particles are necessary to initiate an infectious process after inhalation, and this would be determined by how many small droplets containing virus are inhaled, and the virus concentration in any infected person's nasal passages and deeper airways. The importance of generally wearing masks when in public must be emphasized, to help minimize inhalation of viral particles from released droplets. A recent study indicates that young children under age 10 do not transmit the virus as effectively as adults. Youngsters from 10-19 are as effective as adults are.

The U.S. CDC states that initial symptoms in Covid-19 cases are typically a dry cough (in $70 \%$ of cases) along with possible fever, sore throat, and body aches. These symptoms cause people to seek to be tested for the virus. It should be noted that use of steam and nasal lavage could lower virus titers and could interfere with the detection of the virus measured in nasal swabs or in saliva. After a positive test, or at any time if no test will be sought, use of steam or heated air should be considered a helpful practice.

Figure 11 shows the increasing percent lethality of confirmed cases in the U.S. as a function of time for days ranging from March 24 to May 27, 2020. The total cases listed here are for the most part those individuals who presented to clinics to ask for testing, either because of the presence of symptoms or due to suspected exposure. The number of deaths are also believed to be underestimates since an estimated $28 \%$ of the total deaths are 'silent deaths' at home without being tested. This may be partially offset by any deaths actually caused by another underlying condition in those testing positive.

Studies in Santa Clara CA and in Massachusetts found that $30-50 \%$ of those infected are asymptomatic but have antibodies to the virus indicating exposure. So the general population is believed to have a much higher incidence of infection where half may be asymptomatic and do not become tested so that the total infected would be over twice the cases confirmed from testing. The \% lethality increases over time because deaths follow initial infection data by about two weeks. It is expected that the U.S. lethality percent will approach that found for the rest of the world. Indeed, as of April 26, 2020 it appears the U.S. reached a plateau, a high plateau, with 30,000 new cases and 
3,000 deaths daily, about the world average of $7 \%$. In May the incidence of new cases in New York City are declining, while the incidence of new cases for the rest of the U.S. are rising and the \% lethality held constant over this chronic period. After Memorial Day when many cities and states in the U.S. began to "reopen," spikes in incidence began again. In the month of June, while NY continued to decline in reported new cases, the U.S. incidence of new cases rose. This was associated with a \% lethality decrease to $5.2 \%$ by June 22 , with 120,225 total deaths out of 2,298,696 total reported cases. Coinciding with this drop, the world average also dropped to $5.2 \%$ with a large increase in reported cases, with 469,378 deaths out of a total of 9,015,582 reported cases. This effect could also be partly due to increased efficiency of treating the condition, such as use of steroids and RNA replication blocking drugs, and to increased testing of people. The U.S. increased testing capacity significantly after this date so the chart is ended here.

In South Korea the entire course of the pandemic may be mapped from inception to completion since rigorous controls were instituted to bring the incident to an end, including national wearing of masks, widespread testing using tests from the WHO, and contact tracing. Shown in Figures 12,13 are the cumulative confirmed cases of infection and the deaths that occurred later during the course of the entire incident from February to July, 2020. Note that indeed deaths follow a few weeks behind any increase in incidence, and death reductions follow a lag after incidence reduction occurred. The $\%$ lethality increased to $2.4 \%$ on June 4 and at the essential end of the pandemic was $2.2 \%$ after new cases and new deaths came to essentially zero (Figure 14). It is possible that every country after the pandemic reaches an essential endpoint may have differing \% lethality. The \% lethality has the potential to indicate the stage of the pandemic at which a country is at any time. For example Figure 14 indicates the curve completely flattens and begins to decline on May 8, signaling the turning

COVID-19\% Lethality of Confirmed Cases vs Date from $3 / 24$ to $5 / 27 / 2020$

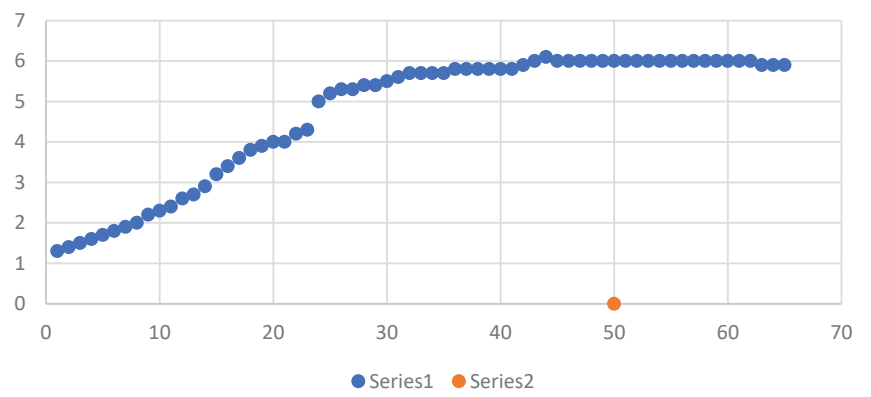

Figure 11: The percent of confirmed Covid-19 infections in the U.S. that are letha is plotted as a function of days from March 24 to May 27 . The world \% lethality at this date is $6.7 \%$ (Johns Hopkins coronavirus tracker) among 5,695,290 confirmed cases and 355,692 deaths, so the U.S. lethality is expected to continue to slowly rise but appears to have leveled. Although the U.S. at this date has $1 / 3$ of the world's total cases $(1,699,933$ cases $)$ it has $1 / 4$ of the world's deaths due to the virus $100,846)$. This is not due to more efficient healthcare but rather to the fact that the US. pandemic began late, where the surge in the number of deaths follows the surge in the number of cases.
Cumulative cases of coronavirus infection from Feb 20 to July 4, 2020 in South Korea

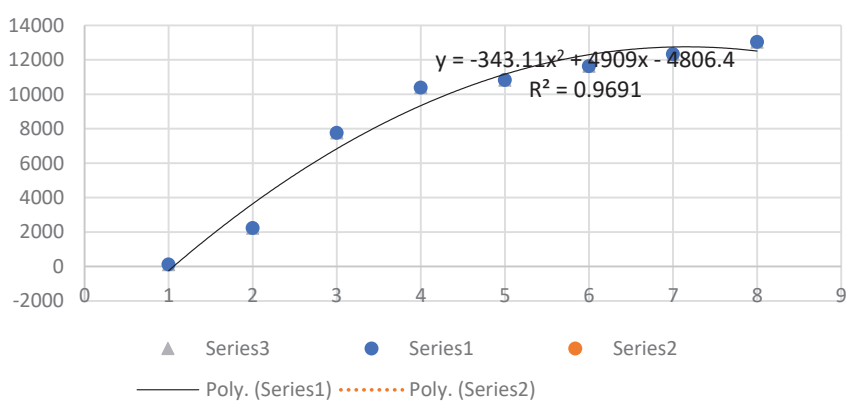

Figure 12: Cumulative confirmed cases of coronavirus infection in South Korea from J February 20, 2020 to July 4, 2020

Deaths from Covid-19 from Feb 20 to July 4, 2020 in South Korea

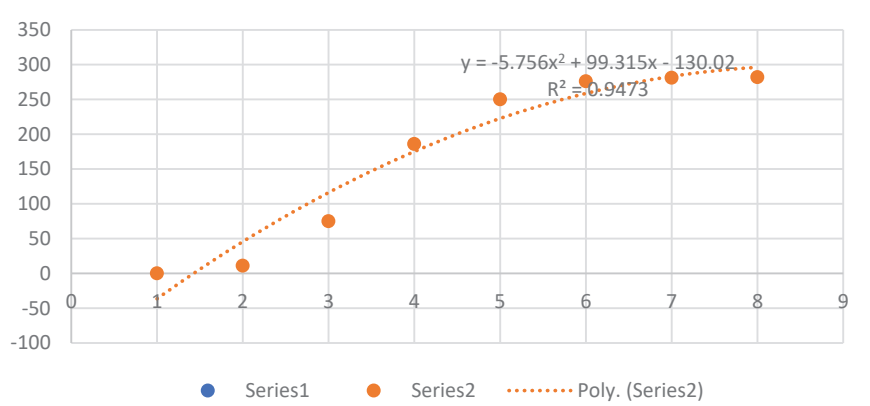

Figure 13: Cumulative number of deaths from Covid-19 infections in South Korea from February 20, 2020 to July 4, 2020.

point to the end of the pandemic, while the total cases and total deaths curves do not reveal this. The situation in those countries that re-open before the pandemic is sufficiently resolved are more complicated, where the \% lethality decreases simply because there are more cases from a re-opening spike, rather than an end of the pandemic.

On July 8, 2020 the lethality ratio was as low as $4.4 \%$ in the U.S. (132,479 deaths among 3,029,297 confirmed cases) which has been attributed to widespread re-opening of society with new cases of infection rapidly increasing. But the phenomenon also appeared to occur generally in many countries around the world with lethality incidence also at $4.6 \%$ due to reported large increases in number of new cases $(545,485$ deaths among 11,892,382 confirmed cases). Therefore it has been largely attributed to "quarantine fatigue" coupled with lack of complete squashing of the incidence curve, where people begin to resume more risky activities again. It was expected that the lethality \% would again rise to near 5-6\% in these countries since deaths of course lag behind new cases by a few weeks. As seen below however, the overall world lethality has remained at $4.2 \%$ even 10 days later. On July 8 Arizona had the highest incidence of positive tests in U.S. States, at $25 \%$ in a region, with Texas at $14 \%$, and Florida at $19 \%$. Contact tracing at this level of infection becomes unmanageable, where the virus has so widely spread into the population. It is difficult to ignore 
\% Lethality of Covid-19 from February 20 to July

\section{4, 2020 in South Korea}

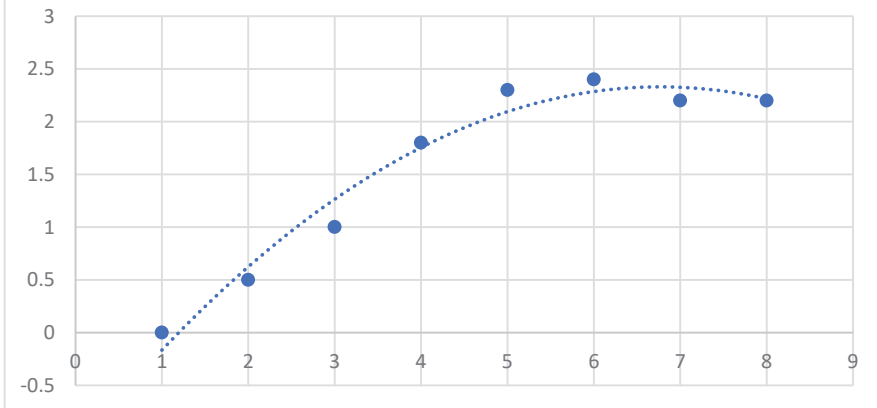

Figure 14: The percentage of Covid-19 cases in South Korea that were lethal increases progressively after the pandemic began, peaks and then declines to the total lethality for the entire pandemic. Dates shown are 1 Feb 2, 2 Feb 28, 3 March 11, 4 April 8, 5 May 8, 6 June 4, 7 June 20, and 8 July 4, 2020

the fact that these States have a majority supporting a political party that does not encourage wearing masks and that decided to widely re-open before the incidence of Covid-19 had been well controlled. In California the State positive test rate is $7 \%$ while the National average on this date is 9\% [16].

There were a total of 232 deaths of 10,653 confirmed cases of Covid-19 infection in South Korea, at 2.2\% lethality. Even though the first case of infection in South Korea occurred the same day the first infection presented in the U.S., the country quickly began mass testing to identify actively infected persons for isolation and contact follow-up. Iceland tested virtually near the entire population and was able to track the virus to block its spread there.

Mass testing in the U.S. as of $4 / 18 / 2020$ remains limited to only $1 \%$ of the population. Thus, asymptomatics in the U.S. have easily caused a widespread incidence of infection in all 50 states. Taos, New Mexico has constrained the infection incidence there from the decision by the county to test the entire population for tracking. Without such tracking, susceptible populations such as the elderly and nursing home residents are subjected to infection from those infected persons having no symptoms. Los Angeles, CA has twice as many people with coronavirus antibodies than those testing positive for active infection. This indicates that a large number of people may be acting as multiples of typhoid Mary who as an asymptomatic carrier of Salmonella typhi was singlehandedly responsible for the infection of thousands of New Yorkers and many deaths until her isolation in 1932.

Especially hard hit are rest homes and elderly care facilities because of the increased susceptibility of the elderly to advanced symptoms of COVID-19, as well as crowded prisons and meat packing plants with employees who are considered essential even during state lockdowns, where workers are forced to be in close quarters. A meat processing plant in South Dakota had 400 infected employees, while the bulk of the state remained mostly unaffected. Five meat packing plants were shut down in Pennsylvania after finding hundreds of infected employees in each facility. Jails and prisons with people in close quarters also exhibit high incidence. And African Americans have a far higher incidence of lethality than Caucasian people. This is not only due to the $12 \%$ difference in high blood pressure incidence between these groups, but may be largely related to the higher incidence of vitamin D deficiency which has been recently reported to be associated with higher Covid incidence [17].

The incidence on May 7, 2020 in the most populated state of California was 2,504 deaths among 62,386 confirmed cases in a population of 39 million people $(0.16 \%$ infection incidence). The incidence in New York State was 26,206 deaths among 332,931 confirmed cases in a population of 19 million people ( $1.8 \%$ infection incidence). The entire U.S. at this date had a $0.36 \%$ infection incidence and a $6 \%$ lethality of confirmed cases compared to the world average of $7 \%$ at this date. California then ranked $5^{\text {th }}$ in total cases, behind New York, New Jersey, Massachusetts, and Illinois as of 5/7/2020 even though $\mathrm{CA}$ is the state with the highest population. Early recommendations to stay at home as much as possible were widely followed and are believed to be the reason for this lower incidence, similar to the outcomes of drastic shutdowns reported by the Endcoronavirus.org group for South Korea, Australia, New Zealand, Vietnam, Thailand, Norway, Austria, Jordan, Luxembourg, Slovenia, Slovakia, Croatia, Lebanon, and Greece, all obliterating their infection rates within months (Figure 15). Due to interstate travel and Federal government pressure to re-open the country for economic reasons, this was expected to change. At this time the U.S. is expanding the contact tracing program around the country to isolate contacts of those known to be infected. Of approximately 150 nations with Covid-19 cases, all have a lower death rate per 100,000 population than the U.S. Seven countries have a higher \% lethality than the U.S., but this ratio of reported cases is steadily increasing as is evident in Figure 11. World cases have also increased, but in the U.S. particularly in States that have politically avoided requiring wearing of masks, such as Florida, Texas and Arizona. hospitalizations and deaths have begun to spike in a manner reminiscent of what took place in New York City earlier. Morgue and intensive care unit beds have reached over or near capacity. At 137,000 deaths in the U.S. as of July 15 , 2020, this is more than the number of Americans killed in the Great War, World War I. A University of Washington analysis projected an estimated 224,000 deaths by November, 2020, which is more than the total killed over a one year span from the two atomic bombs dropped on Hiroshima and Nagasaki combined $(200,000)$. In the fall of 2020 it is anticipated that the virus infection rate will surge into the winter.

On July 22, 2020 California $(409,382)$ finally will surpass New York in total number of detected confirmed cases, as expected since the population of CA (39 million) is twice that of NY. The CA steep rise in cases may be due in part to relaxed restrictions that on this date in CA are now requested again. The increased rate of testing that began in mid-June around the country also caused the detection of more cases but in New York this testing increase did not detect such a dramatic increase in cases. Ultimately the case load reflects the insidious, continuous, spread of the virus. As cases rise in CA however, the \% lethality at this date, a measure of virulence of the 


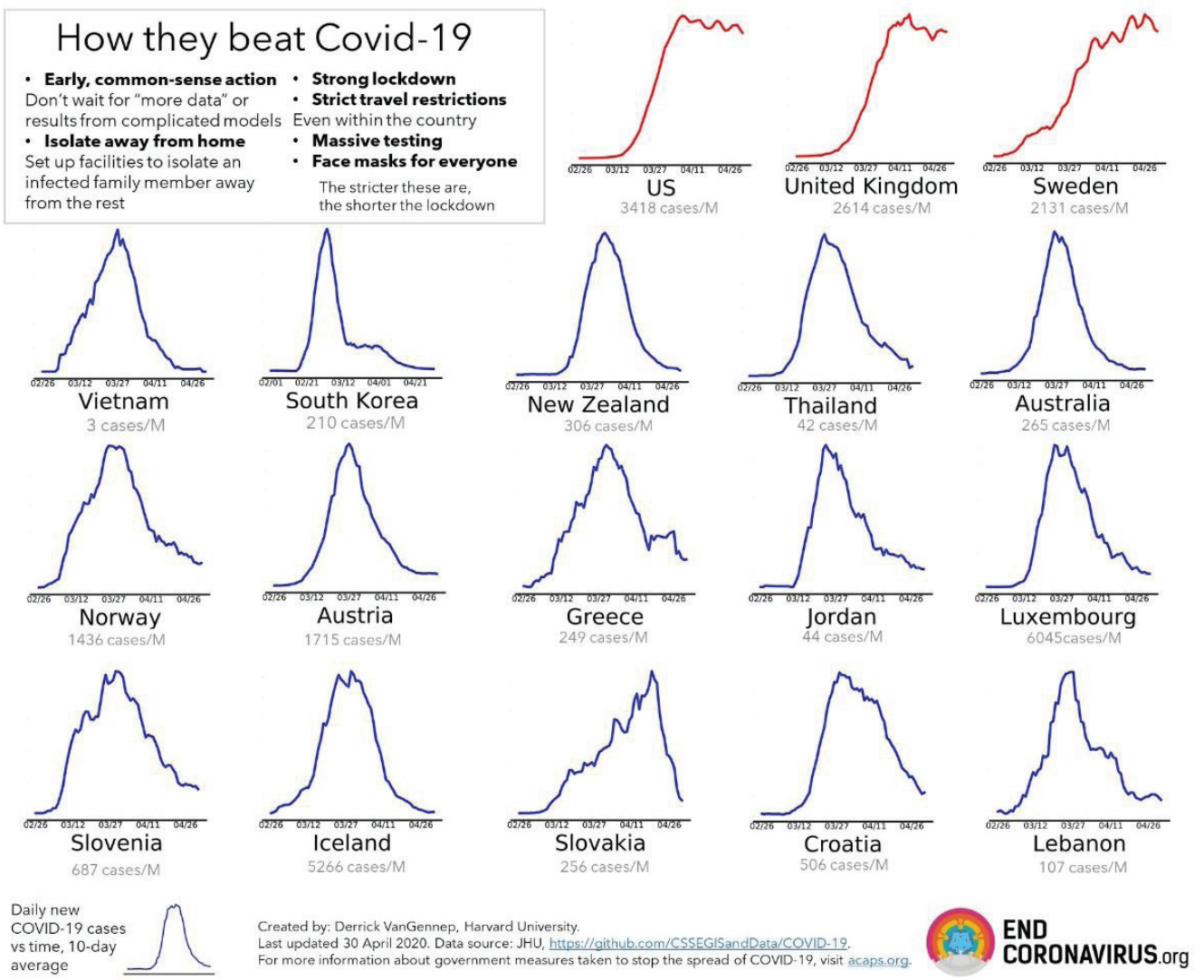

Figure 15: The incidence of new cases of COVID-19 as a function of time in various countries.

novel virus form here, remains at $1.9 \%$, while the incidence, a measure of virus infectivity, for the state reached $1 \%$. It is possible that the incidence will eventually match that in New York and Eastern States. If the form of the virus is indeed less virulent the $2 \%$ lethality would remain. Intermixing of virus mutated forms eventually however would be expected due to travel between States.

Fortunately, South Korean scientists report that infected persons who tested positive after recovery from the illness are not subject to a recurrence of the illness because the tests employed do not distinguish between live virus and viral fragments. Those who recovered were found to all contain inactive viral fragments. Although this suggests that reinfection might not occur for many, a recent report suggests that the virus has mutated worldwide into a variant form that is more infective and that some patients have become symptomatic again after an initial recovery from an initial infection. Indeed, some data indicate that immunity for the virus post-infection may not last long.

The U.S. Surgeon General, Centers for Disease Control and Prevention, declared one week in April, 2020 as the new Pearl Harbor event caused by the death toll from Covid-19. The comparison however is not ideal, where the lethal events from Covid-19 far exceed that from the attack in Hawaii, and the virus illness, that has no recognized treatment, will linger in the civilian population probably for years, and the viral particles, unlike torpedoes and bombs, are invisible, and the infection quickly spread to all 50 U.S. states. Covid-19 lethality is not comparable to lethality from the common flu. The common flu kills an estimated 40,000 people in the U.S. over an entire year (110 daily average). In contrast, as of April 24, 2020, over 50,000 people perished from Covid-19 in the U.S. alone in six weeks (1,200 daily average).

Regular hand washing plus six foot social distancing have been requested for the country by the U.S. CDC during the Covid-19 pandemic. Six feet of separation however should be accompanied with wearing a mask. This is because a sneeze or cough can spew droplets for great distances, far in excess of six feet. Also, while talking face to face, breath can be felt from six feet. Further, small droplets in air can remain for a significant time, especially indoors, so one could actually enter a recent contaminated field without realizing it. Unfortunately, asymptomatic infected people have been found to be responsible for about $50 \%$ of the transmitted cases, likely due to the fact that these individuals remain normally active. Unexpected exposure can occur while practicing social distancing guidelines, where a person could suddenly approach and talk or sneeze while another is inhaling.

Some evidence indicates that viral infections can occur after exposure through the eyes. Thus it also is advisable to wear headgear to protect the eyes and face when one must be in close proximity to others for a significant time, such as children in schools, or as mentioned in populated areas such as prisons or meat packing plants. Inexpensive headgear 
consists of merely a clear acetate sheet attached to a headband. Businesses that should be avoided are indoor gyms and indoor dine-in restaurants. It has been reported that infectivity is 20 times higher for indoor dining than for outdoor dining. This confirms that entrapment of virus particles on small droplets indoors is substantial and that this novel virus behaves similar to other contagious airborne viruses such as measles. Steam or dry heated air inhalation described here, coupled with face washing or even showering and changing clothes, could be a routine procedure performed after any such unexpected exposure, as a prudent prophylactic.

All countries or cities where the infection appears to have run its course and have been controlled with social distancing and mask wearing have produced biphasic curves of incidence. San Diego, CA Covid-19 cases have, for the United States, appeared quite mild for the first few months of time since March, 2020. This is attributed to an early order from the CA governor to social distance and to do essential outside activities only. However the released restrictions on Memorial Day in May appears to have caused a spike in cases. Two different models were used to explain the trend, one plotting cases on a linear scale and another on a logarithmic scale shown in Figure 16 [18]. Although replication of organisms in biological samples always follows an exponential curve, the transmission of virus from infected to non-infected people is not so readily modeled mathematically since transmission depends on behavioral actions of people. Therefore predictions of case numbers in the future can be inaccurate unless a particular population follows a uniform set of guidelines.

On the other hand, principles of the Calculus, namely the first and second derivatives of a function, applied to actual raw data here reveal whether the increasing number of daily deaths are occurring at an increased, or rather a steady or decreased, rate at any particular time. The concavity represents the rate at which the slope of the curve itself is changing over time. Figure 17 is a graph of the accumulated death total from Covid-19 in the U.S. beginning with the first reported death on March 1, through a 140 day period to July 18, 2020 (from Worldometer Covid-19 Data). The second derivative of any mathematical function reflects the curvature or concavity of its Cartesian graph and thus the rate of change for a function such as this with its positive first derivative slope.

The unknown function describing the Covid-19 data here visually varies in curvature over time. The concavity is clearly upward positive over the first 60 days to April 29, then the concavity bends negative while the slope remains positive to day 110 on May 18, and then the curve is concave upward again to day140 (July 18). This supports the argument that, unlike other countries where mask wearing was regulated well until the pandemic was under control, the restrictions that were publicly made after the pandemic began in the U.S. caused a downward curvature to minimize the death accumulation rate only through Memorial Day. After Memorial Day when mask and social distancing restrictions were widely eased, an upsurge again of the death rate re-occurred that has continued through July 18. Since the death rate is independent of testing

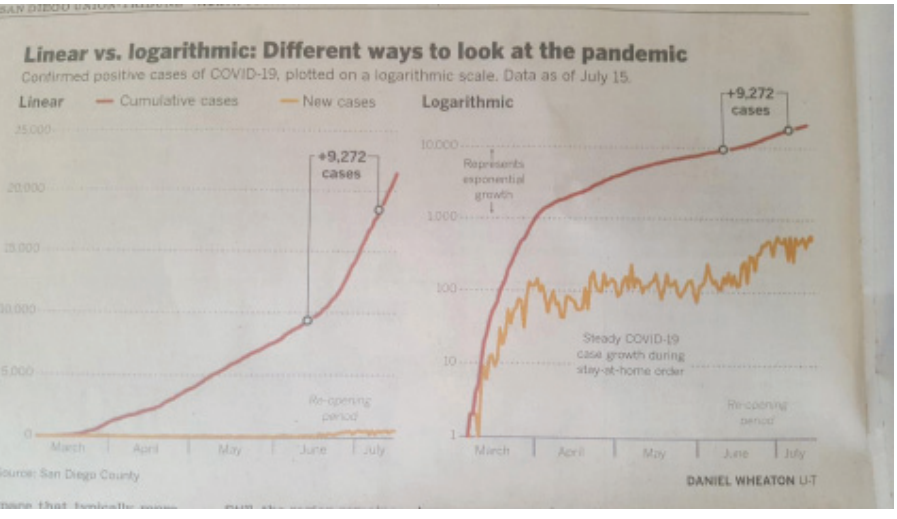

Figure 16: Confirmed Covid-19 cases in San Diego, CA from march to July, 2020 were plotted with ordinal values being placed on either a linear or a logarithmic scale. Transmission of cases among people is highly dependent on wearing of masks, people gathering indoors, social distancing, among other factors and thus are not necessarily amenable to a particular mathematical construct.

Covid19 Death Toll in U.S. from March 1 to July 18,2020

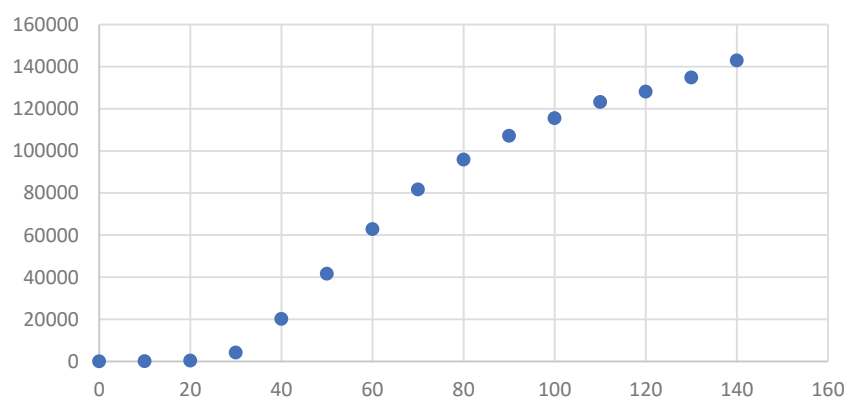

Figure 17: Accumulated deaths in the U.S. due to Covid-19 as a function of days from March 1 (day 0) to July 18 (day 140 ).

rate, this effect has nothing to do with the increase in numbers of tests that progressively increased across the country over this time period.

Although the total deaths in the entire world also now show an upward curvature again, the U.S. cases alone amount toe $25 \%$ of the cases in the world. Note that Germany, Italy, the United Kingdom, and South Korea do not show this large upward curvature seen in the U.S. Other countries with such increasing rates also include Sweden, Brazil, and India. In summary, Covid-19 in mid-April was the leading cause of death in the U.S. at 2,800 deaths per day. In May after behavioral restrictions had been honored, the death rate dropped to 600 per day. Unfortunately after Memorial Day by mid-July the death rate increased again to 1,000 per day without leveling off. The comparison with corresponding employment rates is striking and is the subject of a second article.. It is clear that social distancing and wearing of masks by employees should be more routine actions required by employers and social services in general when at all possible.

The extent of the pandemic and its control vary among the various States, where at least two States, Michigan and New York, have efficiently virtually ended their pandemics by July, 
2020. The \% lethality of confirmed cases around the world as of July 18,2020 was $4.2 \%(608,487$ deaths among $14,608,517$ confirmed cases). There were 26 U.S. States that had less than 1,000 deaths from Covid-19 as of this date. Of the remaining States, ten had a \% lethality substantially higher than the world average (Connecticut 9.2\%, New Jersey 8.9\%, New York $7.9 \%$, Michigan $7.7 \%$, Massachusetts $7.4 \%$, Pennsylvania $6.9 \%$, Indiana $4.7 \%$, Illinois $4.6 \%$, Colorado $4.4 \%$ ). eight were between 2.2 and 4.2\% (Ohio, Maryland, Louisiana, Missouri, Washington, Mississippi, Virginia, Alabama, Georgia), and six were below $2 \%$ (California, Arizona, North and South Carolina, Florida, Texas) [21]. Possible reasons for this are viral mutations causing the existence of two or more strains with differing virulence, or differences in treatment methods, or a long lag that might eventually lead to more deaths in the future. However, the $1.9 \%$ lethality in CA as a whole is also matched by this fraction in Riverside County and in Los Angeles County and in San Diego County, all while various degrees of penetrance or infectivity are present.

San Diego city contains $44 \%$ of the total number of confirmed cases in San Diego County, while surrounding cities have as low $0.1 \%$ of the cases, and yet the overall average for the county is $2 \%$ lethality among the confirmed cases. This consistency in lethality, as a measure of intrinsic virulence of the virus, across the State suggests that the strain of virus that first came to the West Coast from China is different than the strain affecting the East Coast in New York, Connecticut, and New Jersey that arrived from Europe. Although this variety, where a glycine replaced an aspartate in the spike protein, has been argued to be more infective but perhaps less virulent, the facts indicate that the mutated strain that has migrated to Europe and then the U..S. East Coast has actually been more lethal than the strain arriving on the West Coast from China. This is supported by the fact that the \% lethality of confirmed cases in the European Union has chronically been an average $11 \%$ to July 20, 2020 [19-23]. Also as expected, the overall lethality for the South Korea pandemic that arrived directly from China is $2.2 \%$

Tests for the presence of the virus are usually of two types, RNA detection through polymerase chain reaction augmentation of the RNA present in a sample, or testing for antibodies present against viral surface proteins. The first is highly specific but does not distinguish between RNA extracted from live virus particles or from RNA released from fragmented metabolized or degraded virus particles that are no longer infectious. So positive tests would occur in those who have recovered from the disease in addition to those who remain infectious with live virus. The antibody tests likewise do not necessarily distinguish between those in an active infection verses those who have recovered. Positive antibody tests led the U.S. CDC to state that the actual number of infections in the U.S. may be an average 10 times higher than reported cases based on RNA testing. In this regard there would be a use for distinguishing live virus from noninfectious viral fragments. For example, if a large enough sample could be obtained then virus particles could be centrifuged or purified through ultramicron filtration before extracting the RNA for analysis.
This would only detect intact virus particles and could assist health departments with contact tracing to control the spread of active virus, rather than spending resources on tracking non-infectious cases. On July 22, 2020 there were a leading nearly 4 million cases in the U.S., over 2 million in Brazil, over 1 million in India, and nearly 800,000 in Russia in this ongoing, highly fluid, world-wide pandemic.

\section{Summary}

Thoroughly washing nasal passages with hot physiologic saline, and carefully inhaling mildly acidified steam or even heatxed air for a sufficient time and temperature may be of potential help in impeding the progression of COVID-19 infections.

\section{Acknowledgments}

Statements in this article do not necessarily reflect the views of Palomar Community College or its staff. As a victim of advanced serious pneumonia contracted from direct inhalation of coughed droplets from an ill individual, RDS recognizes the benefits of proper steam heat use firsthand for ameliorating respiratory symptoms and in the cure of acne and pyorrhea of gums in the oral cavity. New York Governor Cuomo is thanked for the daily detailed press briefings during the height of the pandemic on the East Coast.

As of September 22, 2020, the first day of Autumn, the U.S total deaths reached over 200,000 among nearly 6.9 million confirmed cases $(2.9 \%$ lethality), the fourth worst per capita incidence in the world. Total deaths in the world are 967,000 among 31 million cases ( $3.1 \%$ lethality). Next in line total deaths are Brazil at 137,000, India 89,000, and Mexico 74,000 The U.K. and Israel are re-instituting severe restrictions considered 'lockdowns' to help slow recent spikes in cases. (Johns Hopkins, reported by the Associated Press, September 23, 2020 'U.S. virus death toll tops 200,000,' San Diego Union Tribune).

The fact that the Covid-19 pandemic outbreak initially began within yards of a Wuhan laboratory, and has accidentally killed over 1 million people on earth, suggests that the practice of intentionally infecting human cell lines with wild viruses should be discontinued and considered unethical worldwide.

\section{References}

1. Bastacky J, Lee CYC, Goerke J, Koushafar H, Yager D, et al. (1995) Alveolar lining layer is thin and continuous: low-temperature scanning electron microscopy of rat lung. J Appl Physiol 79: 1615-1628. Link: https://bit.ly/2Eu6bdX

2. Deng X, Mettelman RC, O'Brien A, Thompson JA, O'Brien TE, et al. (2018) Analysis of Coronavirus Temperature-Sensitive Mutants Reveals an Interplay between the Macrodomain and Papain-Like Protease Impacting Replication and Pathogenesis. Journal of Virology 93: e02140-18 Link: https://bit.ly/2RWWUyh

3. Ishigaki K, Morimoto K, Chatani E, Ozaki Y (2019) Exploration of insulin amyloid polymorphism using Raman spectroscopy and imaging. BioRxiv Cold Spring Harbor Laboratory Link: https://bit.ly/3i7eCKd

4. Duan SM, Zhao XS, Wen RF, Huang JJ, Pi GH, et al. (2003) SARS Research Team. Stability of SARS coronavirus in human specimens and environment 
and its sensitivity to heating and UV irradiation. Biomed Environ Sci 16: 246 255. Link: https://bit.ly/3iZOJyF

5. Ou X, Liu Y, Lei X, Li P, Mi D, et al. (2020) Characterization of spike glycoprotein of SARS-CoV-2 on virus entry and its immune cross-reactivity with SARS-CoV. Nat Commun 11: 1620. Link: https://bit.ly/3kHz71B

6. Sonne O, Gliemann J, Linde S (1981) Effect of pH on binding kinetics and biological effect of insulin in rat adipocytes. J Biol Chem 256: 6250-6254 Link: https://bit.ly/3mQWG9U

7. Bosch BJ (2013) The Coronavirus Spike Protein Is a Class I Virus Fusion Protein: Structural and Functional Characterization of the Fusion Core Complex. Journal of Virology 77: 8801-8811. Link: https://bit.ly/2RWGJkm

8. Singh M, Singhi S, Walia BN (1990) Evaluation of steam therapy in acute lowe respiratory tract infections: a pilot study. Indian Pediatrics 27: 945-951. Link: https://bit.ly/330vtKI

9. The repiratory tract and its infections, Harvard Health Letter (2010) Harvard Health Publishing, Harvard Medical School Link: https://bit.ly/2RSq4yj

10. Chan KH, Malik Peiris JS, Lam SY, Poon LLM, Yuen KY, et al. (2011) The Effects of Temperature and Relative Humidity on the Viability of the SARS Coronavirus. Advances in Virology 2011: 734690 Link: https://bit.ly/3jOhMR8

11. Johns Hopkins Coronavirus Resource Center. Link: https://bit.ly/3kGt2Cw

12. Qiang G, Bao L, Mao H, Wang L, Xu K, et al. (2020) Development of an inactivated vaccine candidate for SARS-CoV-2. Science Link: https://bit.ly/3i7ceDf

13. Folegatti P, Ewer J, Aley KP, Angus B, Becker S, et al. (2020) Safety and immunogenicity of the ChAdOx $1 \mathrm{nCoV}-19$ vaccine against SARS-CoV-2: a preliminary report of a phase $1 / 2$, single-blind, randomised controlled trial. Lancet 396: 467-478. Link: https://bit.ly/3kMIEps

14. Kim J, Chung YS, Jo JH, Lee NJ, Kim MS, et al. (2020) Identification of Coronavirus isolated from a patient in Korea with Covid-19, Osongo Public Health and Research Perspectives 11: 37. Link: https://bit.ly/32WpQww

15. Papineni R, Rosenthal F (1997) The size distribution of droplets in the exhaled breath of healthy human subjects. J Aerosol Med 10: 105-116. Link: https://bit.ly/2FN60va

16. Bean DM, Kraljevic Z, Searle T, BendayanR, Pickles A, et al. (2020) Treatment with ACE inhibitors is associated with less severe disease with SARS Covid 19 infection in a multi-site UK acute Hospital Trust. MedRxiv. Link: https://bit.ly/2RQVkOq

17. Johns Hopkins University. Daily state-by-state testing trends. Link: https://bit.ly/3kNPbyH

18. Hollis B (2020) University of South Carolina. Link: https://bit.ly/3i0qSfp

19. Wheaton D (2020) SD County's Covid-19 curve is no longer flat. San Diego Union Tribune. B6.

20. European Centre for Disease Prevention and Control. COVID-19 situation update for the EU/EEA and the UK, as of 23 September 2020. Link: https://bit.ly/304C6cs

21. Marinetti F (2013) Mary Mallon (1869-1938) and the history of typhoid fever. Ann Gastroenterol 26: 132-134 Link: https://bit.ly/303Sni0

22. Worldometer Covid-19 Data. Link: https://bit.ly/364VU3w

23. Infectious Disease Society of America. Link: https://bit.ly/3kJq0gL
Discover a bigger Impact and Visibility of your article publication with Peertechz Publications

Copyright: @ 2020 Sauerheber RD, et al. This is an open-access article distributed under the terms of the Creative Commons Attribution License, which permits unrestricted use, distribution, and reproduction in any medium, provided the original author and source are credited. 